\title{
Erratum to: Self-regulated learning microanalysis as a tool to inform professional development delivery in real-time
}

\author{
Erin E. Peters-Burton ${ }^{1} \cdot$ Ivan S. Botov $^{1}$
}

Published online: 30 March 2017

(C) Springer Science+Business Media New York 2017

\section{Erratum to: Metacognition Learning (2017) 12:45-78 \\ DOI 10.1007/s11409-016-9160-z}

The original version of this article unfortunately contained a mistake. The blinded version of the article was published. Please find the author citations for the article below.

Peters-Burton, E. E. (2015). The relationship of goal setting and teacher learning in professional development settings. In B. Higgins (Ed.) Goal setting and personal development: teachers' perspectives, behavioral strategies and impact on performance (pp. 15-33). Hauppauge, NY: Nova Publishers.

Peters-Burton, E. E., Cleary, T. J., \& Forman, S. (2015). Professional development contexts that promote self-regulated learning in trainees. In T. J. Cleary (Ed.) Self-regulated learning interventions with at-risk populations: Academic, mental health, and contextual considerations (pp. 205-227). New York: APA Press.

Peters-Burton, E. E. \& Hiller, S. R. (2013). Fun science: The use of variable manipulation to avoid content instruction. Journal of Science Teacher Education, 24, 119-217. doi: 10.1007/s10972-012-9269-0

Peters, E. E. \& Kitsantas, A. (2010). The effect of nature of science metacognitive prompts on science students' content and nature of science knowledge, metacognition, and self-regulatory efficacy. School Science and Mathematics, 110, 382-396. doi:10.1111/j.1949-8594.2010.00050.x

The online version of the original article can be found at http://dx.doi.org/10.1007/s11409-016-9160-z

Erin E. Peters-Burton

epeters1@gmu.edu

1 College of Education and Human Development, George Mason University, 4400 University Drive, MSN 6D2, Fairfax, VA 22030, USA 